\title{
From the design to implementation: the case of the Health Care Integration Councils (CIRA) in Chile
}

\author{
Oscar Arteaga ${ }^{1 *}$, Alejandra Fuentes ${ }^{1}$, Olga Toro $^{2}$, Alex Alarcón $^{1}$ \\ From International Society for Equity in Health: 6th International Conference 2011 \\ Cartegena, Colombia. 26-28 September 2011
}

\section{Background}

In Chile, primary health care is under municipal administration since 1981 [1]. Hospitals are under administration of geographical health services. This separation has been deemed as an obstacle for an integral functioning of the health care network [2]. In the 2005 health reform in Chile, an administrative arrangement called Health Care Integration Council (CIRA) was set. CIRAs were created in each one of the 29 geographic Health Services (HS), with the purpose of facilitating the development of collaborative relationships among providers within the health care network (see figure 1). The legal framework that regulates CIRA considers the inclusion of private providers and does not include community organisations. The purpose of this study was to explore the views of relevant stakeholders belonging to CIRA on the process of moving from design to implementation of the CIRA policy.

\section{Material and methods}

Thirty five semi-structured interviews were carried out to members of CIRA belonging to a purposive sample of six HS in different regions of the country. All the interviews were recorded after participants' informed consent. Interviews were performed and analyzed by the group of researchers using Grounded Theory.

\section{Results}

Stakeholders' perceptions are that CIRAs have been implemented in ways that depart from what was designed in the regulatory framework. This is particularly evident in relation to CIRA members, selection procedures and partially regarding to CIRA role. The regulatory framework is not explicit about the selection of their members. CIRAs were implemented in each HS differently: from non-participatory and rather authoritarian appointment of members to democratic election of some of them. In the regulatory framework CIRA had an advisory role and according to interviewees' general perceptions, this role is being accomplished. However, the view of some stakeholders is that, in practice, this role has turned CIRA into a structure to exchange information only. Interviewees recognize important contributions coming from CIRA policy. Regardless the ways in which CIRAs were implemented, stakeholders agree to see them as an institutionalized space within the health care network. All levels of health care acknowledge CIRA existence, the issues that are discussed, and respect the decisions taken in this Council.

\section{Conclusions}

Although CIRA has been implemented differently from that stated in norms when it was created (e.g. integrating 


\section{CIRA in the organization of the Health Sector in Chile}

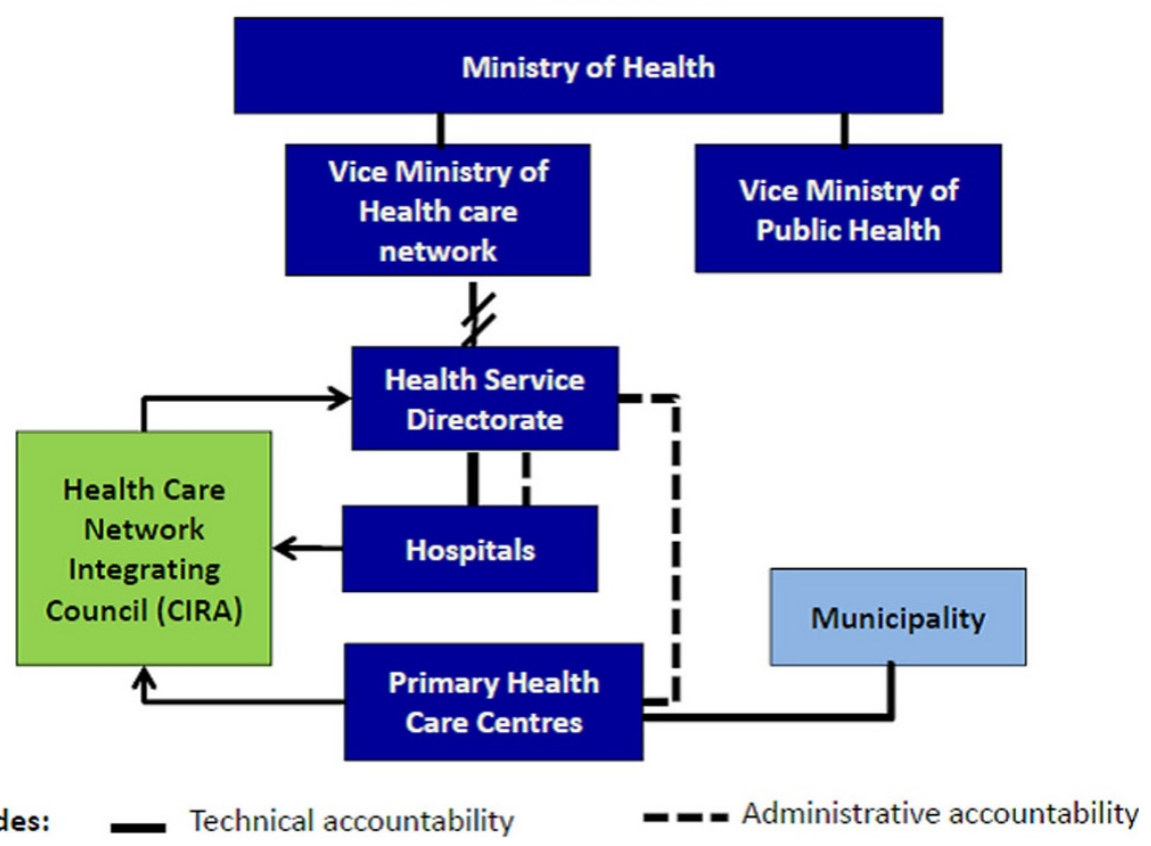

Figure 1

members), CIRA is valued as a relevant institution within the health care network.

\section{Acknowledgements}

Project funded by a grant (SA09120064) from FONIS (Chilean Health Research National Fund).

\section{Author details}

${ }^{1}$ School of Public Health, University of Chile, Santiago de Chile, Chile.

${ }^{2}$ Hospital Santiago Oriente Dr. Luis Tisné, Santiago de Chile, Chile.

Published: 23 January 2012

\section{References}

1. Arteaga O, Astorga I, Pinto AM: Inequalities in public health care provision in Chile. Cad Saude Publica 2002, 18(4):1053-1066.

2. Unger JP, De Paepe P, Cantuarias GS, Herrera OA: Chile's neoliberal health reform: an assessment and a critique. PLoS Med 2008, 5(4):e79.

doi:10.1186/1475-9276-11-S1-A2

Cite this article as: Arteaga et al:: From the design to implementation: the case of the Health Care Integration Councils (CIRA) in Chile. International Journal for Equity in Health 2012 11(Suppl 1):A2.
Submit your next manuscript to BioMed Central and take full advantage of:

- Convenient online submission

- Thorough peer review

- No space constraints or color figure charges

- Immediate publication on acceptance

- Inclusion in PubMed, CAS, Scopus and Google Scholar

- Research which is freely available for redistribution 